\title{
Rektor C.J.L. Almqvist och personlighetsprincipen
}

\author{
Annika Ullman
}

\begin{abstract}
Principal C.J.L. Almqvist and the principle of personality

The Swedish author and visionary Carl Jonas Love Almqvist (1793-1866) was the principal for twelve years (1829-1841) of the government-initiated pilot school "Nya Elementarskolan" (New Elementary School) in Stockholm. In this position, he argued that both the school and the state should be built on the same basic idea: the right of individual freedom. This argument is often referred to as "personlighetsprincipen" (the principle of personality), a concept launched by another prominent figure of the liberal culture of the time, Erik Gustaf Geijer (1783-1847). This article explores how the principle of personality is expressed in the texts of Almqvist and is mainly built upon the concept's allegorical resources. It examines the thesis that Almqvist's use of the term is best understood if one distinguishes between the political, pedagogical, and existential dimension of the concept. The article ends with some thoughts about the context of the concept and a discussion on whether Almqvist had a greater interest in personalities than in principles.
\end{abstract}

Keywords

C.J.L. Almqvist, the principle of personality (personlighetsprincipen), E.G. Geijer

\section{Inledning}

Ty N.E.S.s [Nya Elementarskolans] grundidé är just Personlighetsprincipens (den indiv. Rätta frihetens) uppväckande till lif. Hvad man kallar Sjelfverksamhet i undervisning (Monit. systemets utgångspunkt och stöd) är intet annat, inom Skolans område, än Personlighetsprincipen inom Statens.

(C.J.L. Almqvist i brev till vännen J.A. Hazelius, 1843) ${ }^{1}$

Det finns många vägar att närma sig författaren, rektorn och visionären Carl Jonas Love Almqvist (1793-1866) vilket framgår av forskningsintresset kring denne mångsidige aktör och skribent. ${ }^{2}$ Ett hittills oprövat sätt är att börja i personlighetsprinci-

1 C.J.L. Almqvist till J.A. Hazelius [hösten 1843?] i Almqvist, C.J.L., Brev 1803-1866. Ett urval med inledning och kommentarer av Bertil Romberg (Stockholm: Gidlunds förlag, 1968), 182-3.

2 Det finns en omfattande forskning kring Almqvist liv och verk och intresset är alltjämt stort inom flera discipliner. Bara under 2000-talet har det utkommit ett flertal viktiga verk av litteraturvetare, språkvetare, idéhistoriker, retoriker: Jakob Staberg, Att skapa en ny man: C.J.L. Almqvist och Mannasamfund 1816-1824 (Stehag: Symposion, 2002); Jon Viklund, Ett vidunder i sitt sekel: Retoriska studier i C.J.L. Almqvist kritiska prosa 1815-1851 (Hedemora: Gidlunds förlag, 2004); Anders Burman,

Annika Ullman is Associate Professor of Educational Science at the Department of Education, Stockholm University, Sweden.

Email:annika.ullman@edu.su.se 
pen och via den pröva hans bidrag till den svenska utbildningshistorien. Brevcitatet ovan ger då en tydlig startpunkt. Där använder Almqvist begreppet för att skapa samband mellan en pedagogisk modell och ett förändrat statsskick. Han hävdar att både skolan och staten borde byggas på samma grundidé: den rätta individuella friheten. Han påstår också att den omdebatterade växelundervisningsmetoden (ovan refererad till som monitörsystemet) var ett utmärkt sätt att förbereda eleverna för att axla ansvaret som medborgare i en framtida svensk rättsstat. Detta är ett sambandsresonemang som kan tyckas vara lite väl luftigt. Men Almqvist var inte vem som helst att formulera sig i denna fråga. När brevet skrevs hade han själv både gedigna erfarenheter som praktiserande rektor för Nya Elementarskolan och som samhällsdebattör inom utbildningsområdet. ${ }^{3}$ Almqvists insats hade inte bara varit att förverkliga Snillekommitténs idé om ett försöksläroverk med dubbla bildningslinjer (latin- och reallinje), med växelundervisning, ämneslärare och individuell studietakt. ${ }^{4}$ Under sina tolv exekutiva år som rektor (1829-1841) hann han också sätta sin personliga prägel på det av kommitteen fastställda utbildningsprogrammet. ${ }^{5}$ Genom

Politik i sak: C.J.L. Almqvists samhällstänkande 1839-1851 (Stehag: Symposion, 2005); Per Mårtenson, Stilstudier i Carl Jonas Love Almqvists exilförfattarskap (Stockholm: Almqvist \& Wiksell 2005); Klaus Müller-Wille, Schrift, Schreiben und Wissen: Zu einer Theorie des Archivs in Texten von C.J.L. Almqvist (Tübingen \& Basel: A. Francke Verlag, 2005); Gunilla Hermansson, Att fortaelle verden: En studie i C.J.L. Almqvists Törnrosens bok (Hellerup: Förlaget Spring, 2006); Johan Svedjedals tre volymer: Kärlek är: C.J.L. Almqvists författarliv 1793-1833 (Stockholm: Wahlström \& Widstrand, 2007); Rosor, törnen: C.J.L. Almqvists författarliv 1833-1840 (Stockholm: Wahlström \& Widstrand, 2008) och Frihetens sak: Carl Jonas Love Almqvists författarliv 1841-1866 (Stockholm: Wahlström \& Widstrand, 2009). Även om samtliga dessa verk på lite olika sätt tangerat Almqvist pedagogiska författarskap vill jag hävda att mycket återstår när det gäller att placera in hans betydelse i ett utbildningshistoriskt sammanhang. Almqvists pedagogiska skriverier har egentligen endast stått i ett eget fokus i Hedwig Petri-Liljekrantz, Carl Jonas Almqvists pedagogiska verksamhet (Stockholm: Pedagogiska skrifter utgivna av Sveriges allmänna folkskollärarförenings litteratursällskap, häfte 105, 1923) och i Louise Vinges artikel "Almqvist - läraren" i antologin Carl Jonas Love Almqvist: Konstnären, journalisten, pedagogen, red. Roland Lysell och Britt Wilson Lohse (Hedemora: Gidlunds förlag, 1996). Bland de få utbildningshistoriker som bidragit till att placera in Almqvist i sitt reformpedagogiska sammanhang finns Per-Johan Ödman, Kontrasternas spel: En svensk mentalitets- och pedagogikhistoria (Stockholm: Norstedts, 1995) samt i viss mån jag själv genom Rektorn: En studie av en titel och dess bärare (Stockholm: LHS förlag, 1997). Härtill vill jag särskilt lyfta fram Lars Burmans 33-sidiga inledning till nyutgivningen av "Om Svenska Uppfostringsväsendet" i C.J.L. Almqvist, Samlade Verk 16 (Stockholm: Svenska Vitterhetssamfundet, 2007) som erbjuder den mest koncentrerade och läsvärda inplaceringen av Almqvists utbildningsmanifest från 1839-års artikelserie och 1840-års bok.

3 Denna artikel är skriven inom ramen för mitt pågående forskningsprojekt: "C.J.L. Almqvist som rektor och pedagogiska utopist" som ingående behandlar Almqvists olika insatser på det pedagogiska området. Planerad bokutgivning 2015.

4 Snillekommittén eller Stora uppfostringskommittén som den egentligen hette arbetade 1825-1828 och brukar betraktas som en av de viktigaste milstolparna i den svenska utbildningshistorien. Bland de verk som ingående behandlar idéer och aktörer kring utbildningsfrågan under den första halvan av 1800-talet kan nämnas Lars H. Nilén, Nyhumanism och medborgarfostran: Åsikter om läroverkets målsättning 1820-1880 (Lund: Gleerup, 1975); Esbjörn Larsson, Från adlig uppfostran till borgerlig utbildning: Kungl. Krigsakademien mellan åren 1792 och 1866 (Uppsala, Acta Universitatis Upsaliensis, 2005); Thomas Neidenmark, Pedagogiska imperativ och sociala nätverk i svensk medborgarbildning 1812-1828 (Stockholm: Stockholms universitet, 2011).

5 Om skolan och Almqvists tolv år långa rektorsperiod kan man läsa i jubileumskrifterna: Gustaf Sjöberg, Bidrag till Nya Elementarskolans historia under de första femtio åren av hennes tillvaro (Stockholm: Samson \& Wallin, 1878); Henning Wijkmark, Från Nya Elementarskolans ungdomstid: Festskrift vid skolans 100-årsjubileum (Stockholm: P.A. Norstedt \& söners förlag, 1928); Sigurd Åstrand, Försöksverksamheten vid Nya Elementarskolan (Stockholm: Nya Elementarskolans kamratförening, 1978); Thor Nordin, Nya Elementarskolan i Stockholm: Ett försök att förverkliga frihetens och jämlikhetens idéer. 1 Skolans tillkomst och det första organisationsskedet (Uppsala: Institutionen för pedagogik, 1978). 
att skriva en stor del av skolans läroböcker fick han ett unikt inflytande över den pedagogik och det ämnesinnehåll som gavs i kurserna. ${ }^{6}$ Under samma 1830-tal som Nya Elementarskolan var hans borgerliga näring - och han mest produktiva litterära period (!) - lät han dessutom publicera flera stridbara programskrifter där han diskuterade utbildningsväsendets betydelse för samhällsutvecklingen. ${ }^{7}$ C.J.L. Almqvist var vid denna tid en av Sveriges mer kända samhällsprofiler som kopplade samman förändringar i det lilla med förändringar i det stora. Att han, som i brevcitatet ovan, lyfter fram "Personlighetsprincipen" när han skall förklara sambandet mellan Nya Elementarskolans pedagogiska program och medborgarstatens positiva utveckling, kan möjligen synas lite märkligt. Hösten 1843 när brevet skrevs, var han inte längre rektor och ingenstans tidigare hade han använt just detta ord i samband med skolans grundläggande ideal och pedagogiska program. Trots detta finns det mycket som pekar på att begreppet - med dess olika skikt av betydelser - kanske är ett av de allra viktigaste för att förstå Almqvists utbildningspraktik och bildningsvisioner. ${ }^{8}$

I föreliggande artikel undersöks C.J.L. Almqvists personlighetsprincip delvis med hjälp av jämförelser med E.G. Geijers personlighetsprincip. Det är högst rimligt. Inte bara på grund av att det var just Geijer (1783-1847) som i myntade själva glosan utan också för det finns en del forskning kring nyordets betydelse i hans tankevärld. ${ }^{9}$ När jag här intresserar mig för hur personlighetsprincipen kommer till uttryck i Almqvists texter har jag framförallt tagit fasta på begreppets allegoriska resurser. I inledningscitatet såg vi hur han arrangerade liknelsen mellan skolan och staten. Men begreppet används också till mer sublima överföringar inom ramen för bildningsfrågan. Jag kommer här att pröva tesen att Almqvists användning av begreppet bäst förstås om man särskiljer tre olika dimensioner - en politisk, en pedagogisk och en existentiell. Artikeln landar i några funderingar kring personlighetsprincipens sambandsresonemang och en stilla undran om Almqvist inte är mer intresserad av personligheter än av principer.

6 Almqvist skrev sammanlagt åtta läroböcker under sin rektorsperiod: Allmän språklära (Stockholm: Tryckt hos Johan Hörberg, 1829); Svensk rättstafningslära (Stockholm: 1829); Linear-teckning (Stockholm: Tryckt hos Johan Hörberg, 1830); Svensk språklära (Stockholm: M Wirsells förlag, 1832); Räknekonst för begynnare (Stockholm: Tryckt hos Johan Hörberg, 1832); Lärobok i geometrien (Stockholm: M. Wirsells förlag, 1833); Grekisk språklära (Stockholm: W. Isbergs förlag, 1837); Praktisk lärobok i franska språket (Stockholm: W. Isbergs förlag, 1838).

7 Bland Almqvists pedagogiska programskrifter kan särskilt nämnas: C.J.L. Almqvist, "Några drag. Kapitel IX, Rörande elementarundervisningen" [i Skandia: Tidskrift för vetenskap och konst, 1834], i C.J.L. Almqvist: Estetiska, filosofiska och akademiska avhandlingar 1831-1838 i Samlade Verk 3 (Stockholm: Svenska Vitterhetssamfundet, 2010), 88-110; C.J.L. Almqvist, Om svenska uppfostringsväsendet [1839/1840] i Samlade Verk 16 (Stockholm: Svenska Vitterhetssamfundet, 2007); C.J. L Almqvist: Monografi [1844-45] i Samlade Verk 26 (Stockholm: Svenska Vitterhetssamfundet, 1995).

8 Jag vill hävda att själva tankefiguren fanns tydligt etablerad redan i tidigare textsammanhang. En tydlig pendang till brevcitatets påstående - fastän utan omnämnande av "personlighetsprincipen" - finns t.ex. formulerat i Almqvists tidigare nämnda Skandia-artikel från 1834, i Samlade Verk 3 (2010), 108.

9 Erik Gustav Geijer var professor i historia och författare. Han hade tillhört det konservativa lägret inom Snillekommittén men intog under slutet av 1830-talet istället en politiskt liberal position. Geijer var tillika under fyra omgångar $(1822,1830,1836$ och 1843-1844) rektor för Uppsala universitet. 


\section{1) Den politiska dimensionen}

Den politiska dimensionen av "personlighetsprincipen" kan ses som en direkt artikulering av den franska revolutionens rättighetsförklaring: Frihet genom jämlikhet, men också frihet genom rätten att vara olik. Detta är vad E.G. Geijer lade in i begreppet när han myntade det under slutet av 1830 -talet, ${ }^{10}$ och det var också vad C.J.L. Almqvists tog fasta på när han plockade upp det strax därpå. ${ }^{11}$

\section{I agitation mot ståndsriksdagen}

Med den personliga rätten som alltings början och mål, var både Almqvist och Geijer under 1830- och 40-talen framträdande förespråkare för en ny stat som skulle vara både emanciperande och skyddande. De menade att det fanns en stark politisk potential hos den fria och självständiga medborgaren och de ansåg att tiden var inne för konstitutionell förändring. Idéhistorikern Anders Burman ger i Politik i sak: C.J.L. Almqvists samhällstänkande 1839-1851, en viktig bakgrundsteckning till hur just "personlighetsprincipen" kom att spela en särskild roll i den svenska demokratioch representationsdebatten under den här tiden. ${ }^{12}$ Den direkta inspirationskällan torde varit Alexis de Tocqueville och hans De la démokratie en Amérique (utgiven på svenska som Om folkväldet i Amerika) som när den kom ut vid mitten av 1830-talet medverkade till att vidga demokratibegreppet så att det inte bara pekade på en specifik styrelseform, utan också kom att omfatta sådant som har med "sederna och de mellanmänskliga relationerna att göra". ${ }^{13}$ Det var alltså i denna utvidgningsprocess som personlighetsprincipen kom att passa så bra eftersom den sträckte sig både mot rättighetsaspekterna (en man - en röst) och mot kvalifikationsaspekterna (utbildning åt alla). Härtill öppnade personlighetsprincipen också upp för att det kanske inte var likheten utan olikheten som var själva urkraften i ett demokratiskt system. Ty om så var fallet, så måste ju förändringar i representationsformen också motsvaras av reformer som kunde understödja ett samhällsklimat som hyste respekt för människors olikheter. Häri var Almqvist och Geijer av precis samma uppfattning. Det är, som Anders Ehnmark formulerar det i sin Geijerbok, helt enkelt "det konfliktfyllda mötet som är kärnan i personlighetsprincipen. Om en är underordnad en annan kan mötet inte äga rum. Förutsättningen är jämlikhet." ${ }^{14}$ Ett viktigt bidrag till förståelsen av denna idépolitik är Henrik Berggrens och Lars Trägårdhs Är svensken människa? Gemenskap och oberoende i det moderna Sverige där de till och med utnämner personlighetsprincipen till ett av de mest intressanta begreppen för att förstå svensk 1800-talsliberalism. ${ }^{15}$ Men Geijer och Almqvist bidrog, som vi snart skall se,

10 Se t.ex. Elsa Norberg, Geijers väg från romantik till realism (Stockholm: Svenska kyrkans diakonistyrelses bokförlag, 1944); Carl-David Hessler, Geijer som politiker II, hans senare utveckling (Stockholm: Hugo Gebers förlag, 1947); Anders Ehnmark, Minnets hemlighet (Stockholm: Norstedts, 1999); Anders Jeffner, "Geijers personlighetsfilosofi" i Geijer-jubileet i Uppsala 1983. Föreläsningar vid symposium 12 och 13 januari 1983 (Uppsala: Acta Universitatis Upsaliensis, 1983), 111-25.

11 Det första belägget på att Almqvist använde begreppet i skrift är i samband med den s.k. Det går an-striden: "Bidrag till Det-går-an-litteraturen" [Aftonbladet 31/1 1842] i C.J.L. Almqvists Journalistik, del 1 (1988), 189-193. (Det går an-striden syftar på den uppståndelse som Almqvists roman Det går an väckte när den kom ut 1839 och flera år framåt. Se vidare not 43.

12 A. Burman (2005), se särskilt avsnittet "Personlighetsprincipen och demokratibegreppet", 259-64.

13 Ibid., 260.

14 Ehnmark (1999), 118.

15 Henrik Berggren och Lars Trägårdh, Är svensken människa? Gemenskap och oberoende i det moderna Sverige (Stockholm: Norstedts, 2006). 
på lite olika sätt till att peka ut innebörden av ett framtida demokratiskt statsskick samt dess yttersta förutsättning - välutbildade och ansvariga medborgare. ${ }^{16}$

\title{
Samhällsläran som gav argument för ett nytt styrelseskick
}

Den tydligaste överblicken över hur Almqvist utnyttjar den politiska sprängkraften i personlighetsprincipen får vi av hans Monografi där han på drygt 400 boksidor försökt samla sina omstridda ställningstaganden i tidens frågor. ${ }^{17}$ Mest explicit blir han i det kapitel där han steg för steg redogör för sin samhällssyn och förklarar nödvändigheten av ett förändrat politiskt styrelseskick. ${ }^{18}$ Under rubriken "Om de nya samhällslärornas grund. Jämlikhets- och Personlighetsprinciperna" åberopar han tankelinjerna i tidens demokratiska nytänkande.

En af dessa hufvudläror är Personlighetsprincipen, använd på samhället. Grundsatsen omfattar Individernas förhållande till det Hela i staten, ordnadt på rättsgrund och med en åt alla gifven jemlikhet inför lagen, i stället för den olikhet i rättigheter såsom menniskor, hvilken genom våld och godtycke blifvit upprättad till vissa kasters och folkklassers förmån, men till andras förtryck eller åtminstone förfång. ${ }^{19}$

Almqvist framhåller att personlighetsprincipen, även om dess grundsats är jämlikhet, inte på något sätt förnekar den personliga olikheten, varken i andlig eller kroppslig bemärkelse. Det är just i att säkerställa att skillnader i "karaktär, skicklighet, förmögenhet och dylikt" inte skall medföra olikheter inför lagen, som principen har sin främsta mission. Ty det personlighetsprincipen påstår, skriver Almqvist, är att "det inom varje Individ, den lägsta som den högsta, finnes någonting, som konstituerar den till Menniska, och varuti följaktligen en likhet finnes mellan alla." Och det är just denna, "stora och universella likhet" som "uppställer en oafytterlig rättighet för hvarje människa", att bli en del av samhällets styre och rättigheter. ${ }^{20}$ Och det är därför, fortsätter Almqvist, som det borde kunna sägas:

\begin{abstract}
'att samhället är till för menniskornas skull, men icke menniskorna för samhällets' - och se där revolutionens grundtanke! Det är menniskornas rätt, att i Samhället icke se en sin fiende, icke möta en vexationsanstalt till den fattiges roffande och den svages eller okunniges plågande: utan däruti träffa en sin vän, sin hjelp, sitt sanna stöd, icke uteslutande någon enda (af hvad klass och börd som helst) från alla på jorden befintliga medel till andlig och därjemte äfven kroppslig förkofvran, som denna grundtanke påstår. Hvad kan andra sidan säga häremot? ${ }^{21}$
\end{abstract}

16 Se också A. Burman (2005), Bertil Romberg i C.J.L. Almqvist: Liv och verk (Stockholm: Ordfronts förlag, 1993) samt i inledningen till Samlade Verk 26 (Stockholm: Svenska Vitterhetssamfundet, 1995), 20-21, och i Bertil Rombergs inledning till C.J.L. Almqvists Journalistik, del 1, (Stockholm: Gidlunds förlag, 1988), 49-50.

17 C.J.L. Almqvist: Monografi - Samlad och utgifven för att lätta översigten och bedömandet af viss bland tiden frågor [1844-45] i Samlade Verk 26 (Stockholm: Svenska Vitterhetssamfundet, 1995).

18 Samlade Verk 26 (1995), 382-6, "\$. 4. Om de nya samhällslärornas grund. Jemlikhets- och Personlighetsprinciperna".

19 Ibid., 385.

20 Ibid.

21 Ibid., 386. 
Efter att på detta sätt sjungit personlighetsprincipens lov och medborgarrättens absoluta förtjänster går han över till att i nästa stycke varna för att låta "Individualismen slå öfver till egoism" [kursivering i original]. ${ }^{22}$ Ty egoism är precis vad personlighetsprincipen inte handlar om, markerar han. Vare sig historiskt betingade privilegier eller nya förmåner tillskansade genom "falsk rationalism" har något att göra med det rättighetstänkande som här förespråkas. Personlighetsprincipens grundtanke är att ingen - varken som enskild eller som grupp - skall ha rätt att förhäva sig på någon annans bekostnad. Han fixerar sitt resonemang genom att slå fast dess politiska implikationer. "Att hela denna åsikt, till exempel i frågan om representationsförändringen, leder till 'allmänna val', bestrides icke; och skadar ej." ${ }^{23}$ I det tredje och avslutande argumentationsledet fäster Almqvist jämlikhets- och personlighetsprinciperna i tidens brännheta bildningsdebatt. ${ }^{24}$ Och det är också här han sätter in sin verkliga stöt. Hur kan någon på allvar mena att den ytliga salongsbildning som flertalet riksdagsmän besatt skulle vara en verklig grund för ett medborgerligt samhällsansvar?

\begin{abstract}
Salongernas män skilja sig från Bonden mest deruti, att de kunna säga hvad mycket heter på franska, tyska, engelska och latin, som han endast vet att benämna på svenska: de förmå härigenom bilda en mängd talesätt, som låta mer än de innehålla; men för ämnenas bedömande är detta af ingen vikt. Ej sällan skilja de sig ock från bonden och borgaren däruti, att de hafva ett mera bortkrångladt förnuft, och ogerna draga rena följder eller se slutet af en börjad tanke. ${ }^{25}$
\end{abstract}

Almqvist är inte nådig när han går till attack mot adelns och prästerskapets anspråk på att i alla avseenden överträffa det folkliga förnuftet. Det är knappast detta slag av salongsbildning som bör kvalificera till rösträtt och valbarhet, agiterar han. Nej, det odlade förstånd som man bör kunna kräva av den som tar sitt medborgerliga ansvar i Sveriges riksdag kan man likväl finna inom "kretsen af våra medelklasser och bondiska hus" ${ }^{26}$ och alla bör de ha rätt i att välja sina egna ombud. Almqvist använder alltså "Jemlikhets- och Personlighets-principerna" som grund för att etablera sin argumentation för allmän och lika rösträtt samt möjlighet att kandidera till riksdagen. Den omdömesgilla rättsstat som han förfäktar bygger på de mångas medverkan. Här måste samtliga medborgare få förutsättningar att bära sin del av ansvaret. "En stigande, till alla utsträckt och förbättrad folkuppfostran är ämnad att föra verket till sin egentliga och högre fullkomlighet" ${ }^{27}$

\title{
Med utbildningssystemet som hävstång
}

Både Almqvist och Geijer såg ett utbyggt utbildningssystem som ett av de viktigaste reformkraven. Det var helt logiskt. Det var genom utbildning man skulle 1) lyfta hela folket upp till den ansvarsnivå som ett demokratiskt styrelseskick krävde, 2) säkra framväxten av en samhällsgemenskap bortom förlegade maktordningar och sönder-

22 Ibid., 387-91 "\$. 5. Personlighetsprincipens försvar emot de s.k. Historiskes anfall," citatet från 388.

23 Ibid., 391.

24 Ibid., 391-8, "\$6. Frågan om Bildningens anspråk på rösträtt bland folkombuden".

25 Ibid., 395.

26 Ibid.

27 Ibid., 397. 
slitande särintressen och 3) bygga ett samhälle på en rättvis och meritokratisk grund. Några år innan riksdagen fattade beslutet om en allmän folkskola sammanfattade Almqvist sina argumentationslinjer 1839 i en artikelserie om det svenska uppfostringsväsendet. ${ }^{28}$ Här kan vi se hur han pläderar för en allmän medborgarutbildning och ett överbyggande utbildningssystem som skall garantera att den framtida yrkesbanan kan anläggas med utgångspunkt från den egna unika begåvningen och viljan. Med en folkskola som bas och ett utbyggt läroverkssystem skulle åtminstone de yttre förutsättningarna finnas för en medborgarstat på frihetlig grund. Det är också här vi måste placera in det förebildliga samband som rektor Almqvist menade fanns mellan Nya Elementarskolans pedagogiska ordning och ett framtida styrelseskick på demokratisk grund:

Och den känsla för rättvisa, hvartill gossen uppfostras i N.E. Skolan [Nya Elementarskolan] (att nemligen aldrig befordras till högre Klass förr än vid en viss betygad kunskapsgrad dertill gifver rätt, men deremot alltid då), den skall ute i lifvet och i Samhället nödvändigt en gång göra, att han fordrar samma slags rättvisa der, vid befordringar i statens tjenst liksom i allt annat, hvarefter den gängse Godtycklighetsideen eller Nåden i styrelsesystemet måste komma att anses med fullkomligt ogillande af hela det upppväxande slägte, som uppfostras efter N.E.S.s [Nya Elementarskolan] grundsatser. $^{29}$

Det var inte bara växelundervisningsmetoden som, enligt Almqvist, kunde motiveras med personlighetsprincipen. Minst lika viktig för att bereda marken för ett rättvist samhälle var den fria flyttningen som möjliggjorde att varje elev kunde genomföra utbildningen i egen takt. Att var och en vande sig vid att bli bedömd på sina egna meriter - det var enligt Almqvist en av de viktigaste erfarenheter som skolan kunde bidra med.

\section{Från det stora till det lilla}

I detta socialt oroliga 1800-tal då samhällsupplösning uppfattades som överhängande hot, visade sig "personlighetsprincipen" vara ett utmärkt retorisk redskap. Begreppet passade bra för att skapa tankemässiga paralleller. Ett tydligt exempel är hur Almqvist - här från en artikel i Aftonbladet 1842 - arbetade med att skapa nya samband mellan helheten och delarna:

[...] i den större enhet, som kallas samhälle (vilket själv är ett slags person eller individ, i vidsträktare begrepp), måste likasåväl de enskilda små personerna, som den allmänna, stora personen (samhället) leva oinskränkt med det liv, som tillkommer varje av dem, enligt det sanna upphovet. ${ }^{30}$

För Almqvists var det viktigt att övertyga i denna sak. För att den "stora personen" (samhället) skulle kunna utvecklas optimalt så var det också tvunget att alla de små

28 C.J.L. Almqvist publicerade de 19 artiklarna i Aftonbladet [1839] och gav därefter ut dem som boken Om svenska uppfostringsväsendet [1840] i Samlade Verk 16 (2007).

29 C.J.L. Almqvist till J.A. Hazelius [hösten 1843?] i C.J.L. Almqvist: Brev 1803-1866 (1968), 182-3. De två hakparenteserna i citatet tillagda här.

30 C.J.L. Almqvist i Aftonbladet 31 jan 1842. Från Bertil Rombergs inledning till C.J.L. Almqvists Journalistik, band I (Hedemora: Gidlunds, 1989), 49. Se även A. Burman (2005), 261. 
delarna (individerna) fick möjlighet att växa ut för att kunna ta sitt medborgerliga ansvar. Det var detta som visionären Almqvist såg som själva anslaget för ett nytt och modernt utbildningssystem. Just den här typen av analogier mellan den lilla världen och den stora världen gör också tydligt hur personlighetsprincipen kunde fungera som en slags transformator mellan delvis olika verklighets- och individualitetsuppfattningar. Begreppet tycks hämta sin grundläggande metaforik från romantikens mysticism och abstrakta idealism men samtidigt göra anspråk på att vara ett av de nya verklighetsorden - de som behövdes för att med förnuftets hjälp förändra samhället.

När Almqvist valde att laborera med personlighets-begreppet så att det både omfattade "de enskilda små personerna" och "den allmänna stora personen (samhället)" överförde han medvetet konnotationer från ett användningsområde till ett annat. Man kan säga att han på en och samma gång humaniserade samhället och politiserade medborgarna. Elsa Norberg påpekar tydliga samband mellan personlighetsprincipen och den hegelianism med "aristotelisk accent" som kom på modet $\mathrm{i}$ intellektuella kretsar under slutet av 1830 -talet. ${ }^{31}$ Efter att den romantiska eran ebbat ut kunde man i både Uppsala och i Stockholm se ett ökande intresse för tankesystem som i stället underbyggde "tidens realistiska strävan att komma bort från de tomma abstraktionerna." ${ }^{32}$ Till den aristoteliska influensen räknar hon också den underliggande närvaron av begreppsparet möjlighet (potentia) - verklighet (entelekti), det vill säga att något som fanns som potentialitet också kunde tas fram som aktualitet. ${ }^{33}$ Det är lätt att hålla med. Så gott som alltid när personlighetsprincipen förs på tal frammanas bilden av att det är något som måste befrias. Att det är något som ligger $\mathrm{i}$ vardande som måste få komma till uttryck $i$ enlighet med sin egen bestämning. Eller som Almqvist uttryckte det i citatet ovan: att både den lilla personen och den stora personen måste få rätt att "leva oinskränkt med det liv, som tillkommer varje av dem, enligt det sanna upphovet." [kursivering här] ${ }^{34}$ Med hjälp av personlighetsprincipen byggde Almqvist upp sina argument för demokrati och samhällsreformer med ingredienser av såväl universalitet och unicitet.

\section{2) Den pedagogiska dimensionen}

Tar vi istället utgångspunkt i personlighetsprincipens frammaning av "den lilla personen", av individen, uppenbarar sig ett antal frågor om den mänskliga potentialen. Vilka möjligheter var det Almqvist och Geijer tyckte sig se ligga inbäddade i den mänskliga naturen och hur tänkte de sig att utbildningsväsendet kunde bistå i förverkligandet av denna potential?

\section{Att formas i möten och konflikter}

För både Almqvist och Geijer var det självklart att människan till sin natur är en samhällsvarelse och att denna egenskap är absolut avgörande för hur hon kan full-

\footnotetext{
31 Norberg (1944).

32 Norberg (1944), 67 samt 42-3 där det också påpekas att "det peripatetiska namnet" ibland också rent av användes som en "symbol för den åskådning, som strävar att frigöra sig från de abstrakta skrivbordskonstruktionerna för att i stället orientera sig efter den levande verkligheten."

33 Norberg (1944), 4; Ehnmark (1999), 106-8.

34 Se även hur C.J.L. Almqvist i artikeln "Läroverksfrågan, betraktad af doktor Reuterdahl” [Aftonbladet 28/2 1845] i C.J.L. Almqvists Journalistik, band I (1989) talar om rätten att "lefva och utvecklas efter sin natursanna beskaffenhet, på ett sådant sätt, att det icke sker till någon annans förfång."
} 
följa sin egen bestämning. Det är först genom möten med andra människor som den enskilda kan upptäcka sig själv och utveckla sin naturgivna möjlighet till medkänsla och samhörighet. Potentialen till självmedvetande kunde endast förverkligas genom mötet med en annan. För Geijer var formuleringen "intet du - intet jag", rent av den innersta kärnan i personlighetsprincipen..$^{35}$ Almqvist skulle inte ha uttryckt det riktigt likadant. Visserligen betraktade också han det mellanmänskliga mötet som avgörande för förändring och utveckling. Men det almqvistska sättet att bygga upp och iscensätta utvecklingsförlopp tyder snarare på ett specialintresse för själva skillnaden mellan kontrahenterna. Så även om de båda i princip var överens om att "det konfliktfyllda mötet" var en viktig aspekt av personlighetsprincipens politiska dimension så fanns det en uppenbar skillnad när motsvarande resonemang används för karaktärsdanande resonemang. När konflikttemat applicerades på de identitetsskapande mötena var det bara den Almqvist som var riktigt entusiastisk. Det är som om han hellre ser till det som repellerar än det som appellerar. Hans idévärld är mycket tydligt uppbyggd av polariteter och det är också så han går tillväga när han i skönlitterär form spelar upp antitetiska karaktärer som handlingens viktigaste drivkrafter. Det är i kontrasten och i spänningen som Almqvist ser möjligheterna till utveckling. Men målet för individualiseringsprocessen skall inte förstås som ett växande avstånd mellan individerna utan som en större potential till samhörighet på en samhällelig nivå. Ofta upplöser Almqvist så småningom de synbara motsättningarna i en syntes, på ett högre plan. ${ }^{36}$ Det här är - som litteraturvetaren Jon Viklund påpekar i sin Ett vidunder i sin tid. Retoriska studier i C.J.L. Almqvists kritiska prosa 1815-1851ett av Almqvist effektiva stilgrepp. De antitetiska uppställningarna "där ett begrepp får sin positiva eller negativa laddning i motsättning till sin motsats" ${ }^{\prime 37}$ återfinns på många olika sätt i många av Almqvist skrifter. Bland de exempel som Viklund lyfter fram återfinns intressant nog just "personlighets- och karaktärsaristokrati" och dess kontrast "börds- och penningaristokrati". ${ }^{38}$

\section{Att få lov att bli en egen individ}

Almqvists bildningsbegrepp tar sin utgångspunkt i det klassiska bildningsidealet där detta med att vara och att bli människa är centralt. ${ }^{39}$ Redan i inledningen till $\mathrm{Om}$ svenska uppfostringsväsendet slog han fast att det största felet med de statsbärande institutionerna var att de dittills inte vågat se människan sådan hon verkligen är. ${ }^{40}$ Kyrkan och staten hade, som han uttrycker det, endast velat räkna med "varelser in abstracto" det vill säga varelser, som "efter föreskrift böra kunna blifva hvadsom helst, men förut, eller utan föreskrift, snarast äro ingenting." ${ }^{\text {"1 }}$ Almqvists ideal för en god bildningsgång var precis det motsatta. Var och en måste få möjlighet att utvecklas till en egen individ. Först när utbildningsväsendet vågar erkänna det karakteristiska,

35 Jeffner (1983), 119.

36 Jfr A. Burman (2005), 278.

37 Viklund (2004), 285.

38 Ibid.

39 Se flera av bidragen i Anders Burman och Per Sundgren, red., Bildning: Texter från Esaias Tegner till Sven-Erik Liedman (Göteborg: Daidalos, 2010).

40 C.J.L. Almqvist, Om svenska uppfostringsväsendet [1839/1840] i Samlade Verk 16 (2007).

41 Samlade Verk 16 (2007), 11. 
personliga och det speciella som varje människa både är och måste få vara kan det bli en riktigt positiv kraft i samhällsutvecklingen. Visserligen, fortsätter Almqvist, har både kyrkan och staten legitim rätt att söka binda människorna samman i "stora allmänna föreningsband". Men de måste också besinna att "den man skall taga, måste man först finna”. Almqvists tes är alltså att de samhälleliga institutionerna, istället för att förneka det individuella, måste finna vägar för att stödja och uppmuntra medborgarnas personlighetsutveckling. Kyrkan och staten måste inse "att det individuella icke skall utrotas, utan i det allmänna upptagas;"

ty meniskan skall förbättras, men inte förintas. De skola lära sig att förstå, att allt det egna hos individen är icke förderfligt eller egoistiskt, men att åtskilligt deraf är eller kan blifva så; hvarföre den högsta religiösa visdom, liksom största statskonst består i att urskilja, vhilka egenheter hos menniskan böra återhållas eller understrykas, men hvilka andra, åter, böra framhållas och få fri luft. Denna konst är visserligen svårare än att skära allt över en kam, och sedan, när man misslyckats, icke skylla på sitt eget oförstånd, utan på de enskilda menniskorna, som hafva den elakheten att icke vara tomma abstraktioner, utan lefvande personer. ${ }^{42}$

Själva idén att alla - rika och fattiga, män och kvinnor, barn och vuxna - skulle få möjlighet att växa ut till fullbordade personligheter, var naturligtvis ett djärvt upprop i sig. ${ }^{43}$ Men det som sticker ut mest i Almqvists sätt att resonera är kanske ändå hans hyllning till det mänskliga så som det tar sig uttryck $i$ verkligheten. Till skillnad mot många andra i tidens bildningsdebatt ville Almqvist befria människorna från idealbilderna. Det eftersträvansvärda var inte att bli lika bildad som någon annan utan att bilda sig i enlighet med sin egen potential - och därmed bli alltmer autentisk. Visionären Almqvist tänkte sig alltså ett utbildningsväsende som både förmådde bejaka och befrämja individualitet. Men det är inte några enkla självhjälpsmanualer för ett lyckligare liv som han laborerar med. Tvärt om. För att bära sin egen mänsklighet och ta ansvar för riktningen i sitt eget liv krävs att man konfronterar de existentiella grundvalarna. Den karaktärsdanande aspekterna av personlighetsprincipen ställer, enligt Almqvist, höga krav på en slags etisk (och estetisk!) fostran. Och det är också därför som han förde fram litteraturen, romanen och poesin som helt nödvändiga delar av ett gott uppfostringsprogram. Det är också just i dessa avseenden som vi kan se att rektorn på Nya Elementarskolan överskrider - och utvecklar - det utgångsprogram som en gång gavs Snillekommitténs skolexperimentet. När Almqvist skriver sina läroböcker passar han på att ge ett starkt genomslag för skönlitteratur och lekfullt ordskapande. Här finns också hans starka argument för att lärarna - och monitörerna - så ofta som möjligt bör använda sig av "sokratisk metod” som pedagogisk modell. "Lärjungen bör sättas i den ställning att i sin egen själ liksom uppfinna det,

42 Ibid., 11-2.

43 Att Almqvists låter sin artikelserie om det svenska uppfostringsväsendet ta avstamp i det mänskliga visar hur han beredde marken för att diskutera utbildning utan att fastna i (köns-, klass-, börds-) stereotyper. Almqvist introducerar gärna sina ämnen på sätt som gör det möjligt att komma fram till andra svar än de vanliga. Därigenom kan man också ana vissa förbindelser med den erkänt okonventionella berättelsen som han lät publicera samma år, nämligen Det går an [1839] i Samlade Verk 22. Redigerad och kommenterad av Johan Svedjedal (Stockholm: Svenska Vitterhetssamfundet, 2011). För en mer genomarbetat analys av hur Almqvist gestaltade kvinnor och män hänvisas till standardverket: Karin Westman Berg, Studier $i$ C.J.L. Almqvists kvinnouppfattning (Uppsala: Akademiförlaget Gumperts, 1962). 
hvarom frågan är", som han uttrycker det i en av lärarhandledningarna. ${ }^{44}$ För att lära känna människan - sig själv och andra - är vetenskapen och de generella sanningarna inte nog, hävdade han. Den enda bildning som var mödan värd var den som samtidigt ökade livskänslan. Att bara utsätta ungdomen för tankens förädling var inte tillräckligt. Först när man låter sig beröras av sig själv och andra kan man också ta ansvar för sin egen mänsklighet. Först när man hittat hem i den individuella friheten kan man också vara en medmänniska. I dessa frågor var Almqvist en riktig agitator.

\section{Att söka den egna originaliteten}

Den "rätta" individuella friheten är hos Almqvist alltid en fråga om självständighet och originalitet. I en av de pedagogiska programskrifterna - i Skandia-artikeln från $1834^{45}$ - ger han sig till känna i en av tidens utbildningspolitiska stridsfrågor; latinämnets hegemoniska ställning i den lärda skolan. ${ }^{46}$ Almqvist utmanar idén om latinet som formalbildningsämne. Han ifrågasätter föreställningen om att latinstudier är själva kungsvägen till bildning och ironiserar över att skolgossarna genom de antika texternas hjältedåd själva förmodas bli deras kopior. Men, fortsätter han: vad hade en gång varit själva grunddraget i de gamla grekernas och romarnas handlingar och litteratur? Jo, självständighet! Varje statsman, fältherre och skald som lyftes fram i den klassiska litteraturen framhävdes för att han var "sin egen Individ $i$ sin krets; originell utan att vara sökt". ${ }^{47}$ Just därför var det paradoxalt, menade Almqvist, att den svenska latinundervisningen i början av 1800-talet, hade reducerats till en härmande praktik. Men varför detta fasthållande vid ett dött språk och vid repetitiva exempelläsningar, när det faktiskt var precis motsatsen som kännetecknade själva idealen? Härmed är Almqvist mitt inne i sitt pedagogiska credo: att konsten och de stora texterna är gåvor endast för dem som förmår ta emot dem i sig själva och att bildning därför alltid måste handla om att göra något till sitt eget. Almqvists råd till de svenska läroanstalterna är entydigt. Det bästa sättet att inspireras av antikens fantastiska män och öden, var att söka efterlikna dem i grunden och inte till ytan. "Hvad är, med ett ord, första villkoret för att härma rätt?",

Utan tvifvel det, - att icke härma: men att i sitt slag, sin individ, sitt land, vara en kraftig helgjuten, skön natur, likasom det mönster var, vhilket är frågan om att likna. Denna härmnings-konst (om den så får kallas) består då uti att likna djupet och det verkliga, af det stora mönstret, men ej ytan och de ombytliga formerna. ${ }^{48}$

När Almqvist här hyllar ett autenticitetsideal och förfasar sig över kopians lättviktighet, är det kontextualiserat till latinundervisningen i elementarundervisningen. Men samma grundhållning kommer till uttryck i åtskilliga sammanhang. I nedanstående

44 C.J.L. Almqvist, Allmänna Språkläran (1829), 4.

45 C.J.L. Almqvist, "Några drag", Kapitel IX Rörande elementarundervisningen [i Skandia: Tidskrift för vetenskap och konst, 1834], i Estetiska, filosofiska och akademiska avhandlingar 1831-1838. Samlade Verk 3 (2010).

46 Frågan om latinämnets tyngd i läroplanen var ett av de största utbildningspolitiska trätoämnena under 1800-talet. Standardverket på området är Olof Wennås, Striden om latinherraväldet: Idéer och intressen i svensk skolpolitik under 1800-talet (Stockholm: Almqvist \& Wiksell, 1966).

47 Samlade Verk 3 (2010).

48 Ibid., 94. 
exempel är det konsten och det äkta skapandet som får del i personlighetsprincipens axiom:

\begin{abstract}
Att varje särskilt konstslag, likasom varje enkelt konststycke (vare sig poem, tavla eller tonverk), måste, för att vara äkta, hava sin egen individuellt-karakteristika form. Satsen om allmänna typer eller om allmänna former för konstverk, varuti, oberoende av innehållet, väsendet kan stöpas, innebär då samma orimlighet, som att flera mänskliga personer skulle kunna gå med enahanda gestalt. ${ }^{49}$
\end{abstract}

De människor - och de konstverk - som Almqvist ville se i framtiden var alltså de som hittat "sin egen individuellt-karakteristika form". Så långt kommen i Almqvist användande av personlighetsprincipen måste man påminna sig Donald Broadys, numera klassiska text "Om bildning och konsten att ärva" ${ }^{50}$ där hans viktigaste tes är just att det klassiska bildningsidealet inte kan ärvas genom att efterapas - men att man kan bli en bildad människa genom att rådbråka tidigare generationers erfarenheter och idéer.

\title{
3) Den existentiella dimensionen
}

Geijer och Almqvist använde inte bara personlighetsprincipen för att länka samman "den stora personen" och "den lilla personen". Här finns också, på olika sätt uttryckt, en överordnad dimension. Både Geijer och Almqvist talar om Gud som den "högsta personen" och det eftersträvansvärda att också bli till i mötet med detta gudomliga Du. Men det finns också intressanta skillnader mellan Geijers och Almqvists existentiella strövtåg.

\section{Med Geijers säkra kompass}

För Geijer var personlighetsprincipen, som teologen Anders Jeffner uttrycker det, en totalåskådning. ${ }^{51}$ Det var här han till slut hittade hem när han efter sitt "avfall" från konservatismen 1839 sökte ett nytt sammanhang för sina erfarenheter, tankar och samvetsreaktioner ${ }^{52}$ Jeffner lyfter fram hur Geijer vred och vände på tre grundfrågor - den ontologiska frågan (hur komma runt den kantska dualismen och hitta ett sätt att koppla samman den yttre världen med den inre, upplevda?); den normativt-etiska frågan (hur hitta en systematisk ordning för vad som är gott och rätt?); och den kosmologiska frågan (finns det någon övergripande riktning eller rörelse i den historiska utvecklingen? $)^{53}$ - för att till slut finna svaren i sin integrerande personlighetsprincip. Med personlighetsprincipen som nyckelbegrepp formulerade han sina tre grundpelare: 1) en erfarenhetens grammatik, som slår fast att vi människor behöver varandra både för att veta vem som är vem, och vad som är vad, 2) En etisk-normativ position, som påminner om den kristna gyllene regeln och om Kants människo-

49 C.J.L. Almqvist, C.J.L. Almqvist: Monografi [1844-1845] i Samlade Verk 26 (1995), 104 ("I afseende på Konsterna").

50 Donald Broady, "Om bildning och konsten att ärva", [Kritisk utbildningstidskrift, nr 35-36, 1984] i Bildning: Texter från Esaias Tegnér till Sven-Eric Liedman, red. Anders Burman och Per Sundgren (Göteborg: Daidalos, 2010).

51 Se Jeffner (1983), 111-25.

52 Ibid., 124

53 Ibid., 113. Jeffner bygger sina tre problemformuleringar på hur Geijer tidigare intresserat sig för olika frågor men också på ur diskussionerna gick i Geijers intellektuella miljö. 
värdesprincip; att det goda bottnar $i$ ömsesidighet, i den autonoma viljan att möta varandra med samma respekt som man själv vill bli bemött och 3 ) en tillförsikt till att mänskligheten under historiens lopp gradvis utvecklas till personligheter präglade av de önskvärda etiska ömsesidighetsrelationerna; att samhällsutvecklingen är "analog till personlighetens utveckling $i$ den enskilda människan". ${ }^{54}$ Men utöver detta har Jeffner ytterligare en bestämning av Geijers personlighetsprincip som en totalåskådning. I alla de tre lösningar som personlighetsprincipen erbjuder finns också Gud - den högsta personligheten - närvarande. I den ontologiska dimensionen finns Gud som ett prioriterat $\mathrm{Du}$, alltså som en person som inte kan tänkas isolerad och som just genom att vara i ömsesidighet skapar alla oss övriga "ändliga personer". I den normativt-etiska dimensionen representerar kärleken mellan människor och en personlig gud "det högsta goda i den etik som utgår från personlighetsprincipen." I den kosmologiska dimensionen förlägger han den högsta utvecklingspunkten till en kommande form av kristendom med Johannesevangeliet som föredöme. ${ }^{55}$ I personlighetsprincipen tyckte sig Geijer - som han själv uttryckte det - ha fångat "filosofins högsta och enda sanna princip" ${ }^{56}$

\section{Med Almqvist i labyrinterna}

Almqvists filosoferande kring människans mening och samhällets riktning är knappast ett försök till ett konsekvent tankesystem på samma sätt som Geijer. Almqvist bjuder snarare motstånd mot alla slags försök att komma ända fram. Entydighet och konsistens är inte hans ledstjärnor. Almqvist söker - eller snarare skapar - i stället sin sanningar bland komplikationerna, motsättningarna, inkonsistenserna. Man kan, som Henrik Berggren och Lars Trägårdh utrycker det, se att Almqvist har en osviklig "känsla för existensens grundläggande tragik". ${ }^{7}$ Med sin språkliga gestaltningsförmåga ser han till så att han samtidigt kan prata med flera olika röster - vilket möjliggör att han parallellt kan framföra lite lagom olika uppfattningar. ${ }^{58} \mathrm{I}$ de pedagogiska programskrifterna byggs själva berättarrummet upp av att han både iklär sig rollen som allseende visionär och som strävsam reformrektor. På så sätt kan utbildningsvisionerna skapa tankerymd och förankras i den historiska processen samtidigt som de återkommande hänvisningarna till Nya Elementarskolan får intyga rimligheten och utförbarheten i det lilla. Det är ofta både övertygande och underhållande utfört. Utopisten och rektorn arbetar bra ihop - och det gör förvisso också romanförfattaren. Att Almqvists bildningsvisioner gärna flätas samman med hans poetiska och skönlitterära projekt, är väl uppmärksammat. ${ }^{59}$ Tätt invid artiklarna och pamfletterna kan man höra ekon från Törnrosseriens bildningssalong, från guvernanten Amalia Hillner (i romanen med samma namn från 1840) och från Alexander

54 Fritt efter Jeffner (1983), 24.

55 Ibid., 123-5.

56 Här efter Jeffner (1983), 120.

57 Berggren och Trägårdh (2006), 112-3.

58 Den stilistiska heterogeniteten och stilens metafunktion hos Almqvist diskuteras av Mårtenson (2005), 133ff.

59 Se särskilt Petri-Liljekrantz (1923) och Vinge (1996). 
Medenberg, informatorn i berättelsen om de tre fruarna i Småland.$^{60}$ Man skulle helt enkelt kunna säga att reformrektorn också placerade ut ett antal "hjälplärare" i litteraturen för att där lite friare kunna leka med sina pedagogiska visioner. Johan Svedjedal menar att de här romanhjältarna får fungera som "förmedlande gestalter"; på en och samma gång representanter "för den nya medelklassen" och "föreningslänk mellan himmel och jord". ${ }^{61}$ I de skönlitterära verken får Almqvist framförallt större utrymme att experimentera med de sublima aspekterna av personlighetsprincipen. Hur kan man alls bli en hel och levande människa? Hur kan man alls härbärgera det motsägelsefulla? I Törnrosseriens första bok (av sammanlagt 17 delar) ${ }^{62}$ presenteras ramberättelsen just som ett bildningsprojekt av det storslagna formatet. Varje kväll kommer slottsherren Hugo Lövenstjerna samla sina ungdomar till en berättarsalong där, som det heter, sagan skall elda och glädja, och historien leda och upplysa. ${ }^{63}$ Det är den såväl bokbildade som vittbereste Richard Furumo skall vara deras ciceron. "Kom med dina stycken så, att de alla tillsammans bilda ett enda stort, ordentligt och förståndigt helt" manar Herr Hugo - och Richard Furumo bekräftar att han är helt med på noterna: "Ett levande och sammanhängande helt kan det icke undvika att bliva, herr Hugo, då det flyter utur en enda människas väsende." ${ }^{64}$

När Almqvist är i sin skönlitteratur är han nyfiken på allt. Här kan han experimentera med hur olika delar och helheter kan förstås och gestaltas. Här kan han ägna sig åt zooma in särskilda frågor men också åt att komplicera enkla orsakssamband. Det är också därför han så envetet propagerar för skönlitteraturen i skolan och som bildningsform. Almqvist finner sig inte tillrätta i det tvärsäkra och han tror inte att det högsta bör vara enkelt. "Slösa inte tid och papper på att tala om hurvida folk är brustna eller hela", morrar han en gång i ett brev till en författarkollega. Det är epitet som "passar på ingen": "Hvar och en är nemligen en Person, och personlighetens hemlighet är att vara på en gång både brustenhet, och derjemte alldeles hel ändå." ${ }^{\circ}$

Almqvists existentiella övertygelse är att människans helighet ytterst står att finna i hennes mänsklighet. En viktig aspekt av Almqvists personlighetsprincip pekar följaktligen på vikten av att inte reducera människan till sig själv utan att göra henne mänskligare genom att låta henne bli en del av många mänskliga erfarenheter. Om ungdomarna redan i skolan fick chansen att möta sig själva - och andra människor genom sann konst och äkta litteratur skulle deras anspråk på sig själva och samhället också präglas av djup autenticitet.

60 C.J.L Almqvist, Amalia Hillner [1840] i Samlade Verk 23. Redigerad och kommenterad av Lars Burman (Stockholm: Svenska Viterhetssamfundet, 1995); Tre fruar i Småland, [1844] i Samlade Verk 25. Redigerad och kommenterad av Lars Burman (Stockholm: Svenska Vitterhetssamfundet, 1998).

61 Svedjedal (2009), 42.

62 Törnrosen bok kom under åren 1833-1850 ut i 14 delar inom ramen för den s.k. Duodesupplagan samt 3 delar inom ramen för imperialoktavutgåvan. I och med del 12 förändras ramkonceptet något, berättarsalongen övergår till att bli "Herr Hugs akademi”.

63 C.J.L. Almqvist, ”Jagtslottet: Romantisk berättelse från närvarande tid," Törnrosens bok. Duodesupplagan. Band III [1833] i Samlade Verk 5 (2003).

64 Samlade Verk 5 (2003), 65-6. Liknande tankar uttrycker C.J.L. Almqvist i sin Scandia-artikel om elementarundervisningen från 1834: "Det första vore således, att hos barnet väcka - vett och lif." Om de bara har detta som grund så har de alla förutsättningar att "inhämta de studier och andra ämnen” som de senare behöver, menar han. Här citerad ur Samlade Verk 3 (2010), 89.

65 C.J.L. Almqvist till C. J. Lénström [18 jan 1838], i C.J.L. Almqvist: Brev 1803-1866 (1968), 131. 


\section{Principen och meningssammanhangen}

Efter att ha prövat Almqvist personlighetsprincip i dess politiska, pedagogiska och existentiella dimensioner står det klart att vi inte har att göra med en "princip" i sträng bemärkelse. Däremot är det tydligt att samtliga tre dimensioner behövs för att förstå och fånga upp alla betydelseskikt i Almqvists användning av begreppet. Det blir tydligt att personlighetsprincipen passade utmärkt väl för att föra samman - och korsbefrukta - 1800-talets brännande debattfrågor kring medborgarrollen och utbildningsväsendet. Genom att framkalla bilden av samhället som den "stora personligheten" och individen som den "lilla personligheten" blev bildningsfrågan tillgänglig som sambandsnyckel. Almqvist kunde, liksom Geijer, ta spjärn i "personlighetsprincipen" när han argumenterade för lika rösträtt och ett utbyggt utbildningssystem. Vidare kunde begreppet också, som i det inledande brevcitatet, användas för att legitimera den samhälleliga nyttan av Nya Elementarskolans reformpedagogik. Men trots dessa användbara sambandsresonemang är det uppenbart att Almqvist var mera intresserad av "personlighets"-sidan, eller den existentiella aspekten, av begreppet än av "princip"-sidan. Som i så många andra sammanhang är Almqvist grundmurat skeptisk till just principer och fasta system - eftersom han menar att de har en tendens att bli sig själva nog.

Nota bene. Efter Geijer och Almqvist var det inte många som åberopade just personlighetsprincipen som utgångspunkt i utbildningsdebatten. Bland de få som plockade upp begreppet bör dock nämnas folkskolläraren och ecklesiastikministern Fridtjuv Berg (1851-1916) samt skolstiftarinnan och skriftställaren Anna Sandström, "Uffe" (1854-1831). För Berg, som explicit hänvisade till begreppet som Geijerskt, blev "personlighetsprincipen" ett viktigt retoriskt redskap när han argumenterade för att göra "folkskolan till bottenskola" i det svenska utbildningssystemet. ${ }^{66}$ En mer öppen och associativ begreppsanvändning finner vi hos Sandström som liksom Almqvist - ofta uppehåller sig vid hur utbildningsväsendet skall förmås att understödja personlig utveckling i stället för att ägna sig åt död formalism. ${ }^{67}$

Det som dröjer sig kvar när man följt Almqvists olika sätt att formulera sig och skapa nya meningssammanhang är en personlighetsprincip som också öppnar för en relation till det obegripliga, en vision om hur livet skulle kunna vara annorlunda. Almqvist väjer inte för det oförutsedda eller för att verkliga människor är mer komplexa än modellerna. Han bjuder helt enkelt in till fortsatta funderingar om det möjliga.

66 Fridtjuv Berg, "Geijer som uppfostringstänkare" i Svensk Läraretidning, 14/4 1897 där han också lyfter fram Geijer som sitt pedagogiska föredöme. Se även Klas Bröms och Wilhelm Sjöstrand, Frihet och jämlikhet enligt personlighetsprincipen hos Fridtjuv Berg (Uppsala: Institutionen för pedagogik, 1972), där författarna visar hur konsekvent Berg i sina pedagogiska skrifter hyllar personlighetsprincipen som handlingsgrund för både skola och samhällsliv. Det var också i denna han förankrade sin outtröttliga kamp för att skapa en samlad enhetsskola (folkskolan som bottenskola) istället för det rådande parallellskolesystemet

67 Annika Ullman, Stiftarinnegenerationen: Sofi Almqvist, Anna Sandström, Anna Ahlström (Stockholm: Stockholmia förlag, 2003). 


\section{Referenser}

Almqvist, Carl Jonas Love. Allmän språklära ämnad att grundlägga och förbereda undervisningen $i$ de särskilda språken uti den Nya Elementar-skolan: Reglor för undervisaren. Stockholm: Tryckt hos Johan Hörberg, 1829.

Almqvist, Carl Jonas Love. Svensk rättstafnings-lära innefattande regler för alla $i$ språket förkommande fall upplysta genom exempel: Undantags-förteckningar och Skrif-öfningar. Stockholm: Tryckt hos Johan Hörberg, 1829.

Almqvist, Carl Jonas Love. Linear-teckning ämnad att grundlägga och förbereda undervisningen uti Mathematik. Stockholm: Tryckt hos Johan Hörberg, 1830.

Almqvist, Carl Jonas Love. Räknekonst för begynnare eller Praktisk aritmetik ämnad att genom korta bestämda Reglor samt dertill hörande Exempel bibringa grunderna af Quattuor Species eller de fyra Räknesätten (i hela tal, bråk, decimaler och sorter), Regula de tri (enkelt och sammansatt): Intresse-räkning samt Qvadrat-och Kubik-rötters utdragande. Stockholm: Tryckt hos Johan Hörberg, 1832.

Almqvist, Carl Jonas Love. Svensk språklära. Stockholm: M. Wirsells förlag, 1832.

Almqvist, Carl Jonas Love. Lärobok i geometrien innefattande grunderna för läran om linier, ytor (planimetri) samt solida figurer (stereometri) [1833]. Tredje upplagan. Stockholm: M Wirsells förlag, 1842.

Almqvist, Carl Jonas Love. Grekisk språklära till ungdomens tjenst vid högre och lägre undervisningsverk. Stockholm: W. Isbergs förlag, 1837.

Almqvist, Carl Jonas Love. Praktisk lärobok i franska språket. Stockholm: W. Isbergs förlag, 1838.

Almqvist, Carl Jonas Love. C.J.L. Almqvist: Brev 1803-1866. Urval med inledning och kommentarer av Bertil Romberg. Stockholm: Gidlunds förlag, 1968.

Almqvist, Carl Jonas Love. C.J.L. Almqvists Journalistik I-II. Urval, inledning och kommentarer av Bertil Romberg. Hedemora: Gidlunds förlag, 1989.

Almqvist, Carl Jonas Love. Samlade Verk. Huvudredaktör: Bertil Romberg 19932006, Johan Svedjedal 2007 och fortfarande. Stockholm: Vitterhetsakademin, pågående utgivning sedan 1993.

Almqvist, Carl Jonas Love. Om Manhemsförbundets föreslagna organisation [1821] i C.J. L. Almqvist: Monografi [1845-1846]. I Samlade Verk 26. Redigerad och kommenterad av Bertil Romberg. Stockholm: Svenska Vitterhetssamfundet, 1995.

Almqvist, Carl Jonas Love. ”Jagtslottet: Romantiskt Berättelse ur Närvarande tid” i Törnrosens bok. Duodesupplagen. Band I-III [1833]. I Samlade Verk 5. Redigerad och komenterad av Olof Holm och Petra Söderlund. Stockholm: Svenska Vitterhetsakademin, 2003.

Almqvist, Carl Jonas Love. "Några drag." Kapitel IX Rörande elementarundervisningen [i Skandia: Tidskrift för vetenskap och konst, 1834]. I Samlade Verk 3. Estetiska, filosofiska och akademiska avhandlingar 1831-1838. Redigerad och kommenterad av Jon Viklund. Stockholm: Svenska Vitterhetssamfundet, 2010.

Almqvist, Carl Jonas Love. Om svenska uppfostringsväsendet [1839/40]. I Samlade Verk 16. Redigerad och kommenterad av Lars Burman. Stockholm: Svenska Vitterhetssamfundet, 2007.

Almqvist, Carl Jonas Love. C.J. L. Almqvist: Monografi [1845-1846]. I Samlade Verk 26. Redigerad och kommenterad av Bertil Romberg. Stockholm: Svenska Vitterhetssamfundet, 1995. 
Almqvist, Carl Jonas Love. Amalia Hillner [1840]. I Samlade Verk 23. Redigerad och kommenterad av Lars Burman. Stockholm: Svenska Viterhetssamfundet, 1995.

Almqvist, Carl Jonas Love. Tre fruar i Småland [1844] i Samlade Verk 25. Redigerad och kommenterad av Lars Burman. Stockholm: Svenska Vitterhetssamfundet, 1998.

Almqvist, Carl Jonas Love. "Bidrag till Det-går-an-litteraturen" [Aftonbladet 31/1 1842]. I C.J.L. Almqvists Journalistik I-II. Urval, inledning och kommentarer av Bertil Romberg. Hedemora: Gidlunds förlag, 1989.

Almqvist, Carl Jonas Love. "Läroverksfrågan, betraktad af doktor Reuterdahl" [i Aftonbladet 28/2 1845]. I C.J.L. Almqvists Journalistik I-II. Urval, inledning och kommentarer av Bertil Romberg. Hedemora: Gidlunds förlag, 1989.

Berg, Fridtjuv. "Geijer såsom uppfostringstänkare." Svensk Läraretidning, nr 15, 1897.

Berggren, Henrik och Lars Trägårdh. Är svensken människa? Gemenskap och oberoende i det moderna Sverige. Stockholm: Norstedts, 2006.

Bröms, Klas och Wilhelm Sjöstrand. Frihet och jämlikhet enligt personlighetsprincipen hos Fridtjuv Berg. Uppsala: Institutionen för pedagogik. Volym 12 av Forskningsprojektet Frihet och jämlikhet som pedagogiska grundbegrepp inom västerländsk demokrati, 1972.

Broady, Donald. "Om bildning och konsten att ärva." I Bildning: Texter från Esaias Tegner till Sven-Erik Liedman, red. Anders Burman och Per Sundgren. Göteborg: Bokförlaget Daidalos, 2010.

Broady, Donald. "Bildningstanken krumbukter. Några blad ur historien från 1970tal till 2010-tal." I Svenska bildningstraditioner, red. Anders Burman och Per Sundgren. Göteborg: Daidalos, 2012.

Burman, Anders. Politik i sak: C.J.L. Almqvist samhällstänkande 1839-1851. Stehag: Symposion, 2005.

Burman, Anders och Per Sundgren, red. Bildning: Texter från Esaias Tegner till Sven-Erik Liedman. Göteborg: Daidalos, 2010.

Burman, Lars, "Inledning och kommentarer till Om Svenska Uppfostringsväsendet." I Samlade Verk 16. Stockholm: Svenska Vitterhetssamfundet, 2007.

Burman, Lars, red. Carl Jonas Almqvist: Diktaren, debattören, drömmaren. Almqviststudier 3, Föreläsningar och essäer utgivna av Almqvistsällskapet, Hedemora: Gidlunds förlag, 2001.

Ehnmark, Anders. Minnets hemlighet: En bok om Erik Gustaf Geijer. Stockholm: Norstedts, 1999.

Forsskål, Peter. Tankar om den borgerliga friheten [1759]. Stockholm: Atlantis, 2009. Hermansson, Gunilla. Att fortaelle verden: En studie i C.J.L. Almqvists Törnrosens bok. Hellerup: Förlaget Spring, 2006.

Hessler, Carl David. Geijer som politiker II: Hans senare utveckling. Stockholm: Hugo Gebers förlag, 1947.

Jeffner, Anders. "Geijers personlighetsfilosofi." I Geijer-jubileet i Uppsala 1983: Föreläsningar vid symposium 12 och 13 januari 1983. Skrifter rörande Uppsala universitet, C. Organisation och historia 45. Uppsala: Acta Universitatis Upsaliensis, 1983. 
Larsson, Esbjörn. Från adlig uppfostran till borgerlig utbildning: Kungl. Krigsakademien mellan åren 1792 och 1866. Uppsala: Acta Universitatis Upsaliensis, Studia Historica Upsaliensia 220, 2005.

Lysell, Roland och Britt Wilson Lohse, red. Carl Jonas Almqvist: Konstnären, journalisten, pedagogen. Almqviststudier I: Föreläsningar och essäer utgivna av Almqvistsällskapet, Hedemora: Gidlunds förlag, 1996.

Müller-Wille, Klaus. Schrift, Schreiben und Wissen: Zu einer Theorie des Archivs in Texten von C.J.L. Almqvist. Tübingen \& Basel: A. Francke Verlag, 2005.

Mårtenson, Per. Stilstudier i Carl Jonas Love Almqvists exilförfattarskap. Acta Univeritatis Stockholmiensis. Stockholm Studies in Scandinavian Philology, 39. Stockholm: Almqvist \& Wiksell, 2005.

Neidenmark, Thomas. Pedagogiska imperativ och sociala nätverk $i$ svensk medborgarbildning 1812-1828. Stockholm: Stockholms universitet, 2011.

Nilén, Lars H. Nyhumanism och medborgarfostran: Åsikter om läroverkets målsättning 1820-1880. Lund: Gleerup, 1975.

Norberg, Elsa. Geijers väg från romantik till realism. Stockholm: Svenska kyrkans diakonistyrelses bokförlag, 1944.

Petri-Liljekrantz, Hedvig. Carl Jonas Love Almqvists pedagogiska verksamhet. Stockholm: Sveriges allmänna folkskollärarförenings litteratursällskap, 1923.

Romberg, Bertil. "'Med kompassen i hjärtat' eller Den framsynte Almqvist." I Carl Jonas Almqvist: Diktaren, debattören, drömmaren, red. Lars Burman. Almqviststudier 3, Föreläsningar och essäer utgivna av Almqvistsällskapet. Hedemora: Gidlunds förlag, 2001.

Sanner, Inga. Att älska sin nästa såsom sig själv: Om moraliska utopier på 1800-talet. Stockholm: Carlsson förlag, 1995.

Staberg, Jakob. Att skapa en ny man: C.J.L. Almqvist och Mannasamfund 1816-1824. Stehag: Symposion, 2002.

Svedjedal, Johan. Kärlek är: C.J.L. Almqvist författarliv 1793-1833. Stockholm: Wahlström \& Widstrand, 2007.

Svedjedal, Johan. Rosor, törnen: C.J.L. Almqvists författarliv 1833-1840. Stockholm: Wahlström \& Widstrand, 2008.

Svedjedal, Johan. Frihetens rena sak: Carl Jonas Love Almqvists författarliv 18411866. Stockholm: Wahlström \& Widstrand, 2009.

Tema Carl Jonas Love Almqvist, Res Publica, nr 22. Stehag: Symposion, 1992.

de Tocqueville, Alexis. Om folkväldet i Amerika [De la démokratie en Amérique, 1835]. Stockholm: Norstedt, 1839.

Ullman, Annika. Rektorn: En studie av en titel och dess bärare. Stockholm: HLS förlag, 1997.

Ullman, Annika. Stiftarinnegenerationen: Sofi Almqvist, Anna Sandström, Anna Ahlström. Stockholm: Stockholmia förlag, 2003.

Wennås Olof. Striden om latinherraväldet: Idéer och intressen i svensk skolpolitik under 1800-talet. Skrifter utgivna av Statsvetenskapliga Föreningen i Uppsala XLV. Stockholm: Almqvist \& Wiksell, 1966.

Westman Berg, Karin. Studier i C.J.L. Almqvist kvinnouppfattning. Uppsala: Akademiförlaget Gumperts, 1962. 
Wijkmark, Henning. Från Nya Elementarskolans ungdomstid: Festskrift vid skolans 100-årsjubileum. Stockholm: P.A. Norstedt \& söners förlag, 1929.

Viklund, Jon. Ett vidunder i sitt sekel: Retoriska studier i C.J.L. Almqvists kritiska prosa 1815-1851. Hedemora: Gidlunds förlag, 2004.

Vinge, Louise. "Almqvist - läraren." I Carl Jonas Love Almqvist: Konstnären, journalisten, pedagogen, red. Roland Lysell och Britt Wilson Lohse. Almqviststudier I, Föreläsningar och essäer utgivna av Almqvistsällskapet, Hedemora: Gidlunds förlag, 1996.

Ödman, Per-Johan. Kontrasternas spel: En svensk mentalitets- och pedagogikhistoria. Stockholm: Norstedts, 1995. 